\title{
ANALISIS KANDUNGAN VITAMIN B PADA IKAN SIDAT (Anguilla marmorata (Q.) Gaimard) FASE ELVER ASAL DANAU POSO
}

\section{Analysis of Vitamin B Eel Fish (Anguilla marmorata (Q.) Gaimard) on Elver Phase Origin Lake Poso}

\author{
Fenti*1 $^{1}$, Agustinus Widodo ${ }^{1}$, Jamaluddin ${ }^{1}$ \\ 1. Jurusan Farmasi, Fakultas Matematika dan Ilmu Pengetahuan Alam, Universitas Tadulako, Indonesia
}

Diterima: 30 November 2018; Revisi: 03 Desember 2018; Diterbitkan: 30 Desember 2018

Background \& Objective: Vitamins are complex organic substances that are needed by the body in small amounts, usually cannot be synthesized by the body but are important in metabolic processes one of which is vitamin B. Vitamin $\mathrm{B}$ consists of vitamins B1, B2, B3, B6, B9 and B12. Eel is one of the fish that has a high nutrient content, one of which is vitamin $\mathrm{B}$. This study aims to determine the levels of vitamin $\mathrm{B}\left(\mathrm{B}_{1}, \mathrm{~B}_{2}, \mathrm{~B}_{3}, \mathrm{~B}_{6}, \mathrm{~B}_{9}\right.$ and $\left.\mathrm{B}_{12}\right)$ in Eel fish (Anguilla marmorata (Q.) Gaimard) on Elver phase from Lake Poso. Material and Methods: Determination of vitamin $\mathrm{B}_{1}, \mathrm{~B}_{2}, \mathrm{~B}_{3}$, $\mathrm{B}_{6}$ and $\mathrm{B}_{9}$ using HPLC (High Performance Liquid Chromatography), and vitamin $\mathrm{B}_{12}$ using LC-MS (Liquid Chromatography-Mass Spectrometry) . Results: The levels of vitamin $\mathrm{B}_{2}, \mathrm{~B}_{3}$ and $\mathrm{B}_{12}$ is $0.133 \mathrm{mg} / 100 \mathrm{~g}, 1.895 \mathrm{mg} / 100 \mathrm{~g}$, and $0.017 \mathrm{mg} / 100 \mathrm{~g}$, whereas in vitamin $\mathrm{B}_{1}, \mathrm{~B}_{6}$ and $\mathrm{B}_{9}$ is not detected. Conclusion: Eel fish (Anguilla marmorata (Q.) Gaimard) on Elver phase from Lake Poso can be used as a source of vitamins $\mathrm{B}_{2}, \mathrm{~B}_{3}$ and $\mathrm{B}_{12}$.

Keywords: Vitamins B, Anguilla marmorata, Elver phase, HPLC

Abstrak

Latar Belakang \& Tujuan : Vitamin merupakan zat-zat organik kompleks yang diperlukan tubuh dalam jumlah yang kecil, umumnya tidak dapat disintetis oleh tubuh tetapi penting dalam proses metabolik salah satunya adalah vitamin $B$. Vitamin $\mathrm{B}$ terdiri dari vitamin $\mathrm{B}_{1}, \mathrm{~B}_{2}, \mathrm{~B}_{3}, \mathrm{~B}_{6}, \mathrm{~B}_{9}$ dan $\mathrm{B}_{12}$. Sidat merupakan salah satu ikan yang memiliki kandungan nutrisi yang tinggi salah satunya vitamin $\mathrm{B}$. Penelitian ini dilakukan untuk menentukan kadar vitamin $\mathrm{B}\left(\mathrm{B}_{1}, \mathrm{~B}_{2}, \mathrm{~B}_{3}, \mathrm{~B}_{6}, \mathrm{~B}_{9}\right.$, $\mathrm{B}_{12}$ ) pada ikan sidat (Anguilla marmorata (Q.) Gaimard) fase elver asal danau Poso . Bahan dan Metode : Penentuan kadar vitamin $\mathrm{B}_{1}, \mathrm{~B}_{2}, \mathrm{~B}_{3}, \mathrm{~B}_{6}$, dan $\mathrm{B}_{9}$ menggunakan metode KCKT (Kromatografi Cair Kinerja Tinggi), dan pada vitamin $\mathrm{B}_{12}$ menggunakan metode LC-MS (Liquid Chromatography-Mass Spectrometry). Hasil : Vitamin $\mathrm{B}_{2}$ dengan kadar $0,133 \mathrm{mg} / 100 \mathrm{~g}$, vitamin $\mathrm{B}_{3}$ dengan kadar $1,895 \mathrm{mg} / 100 \mathrm{~g}$, dan vitamin $\mathrm{B}_{12}$ dengan kadar 0,017mg/100g sedangkan pada vitamin $\mathrm{B}_{1}, \mathrm{~B}_{6}$, dan $\mathrm{B}_{9}$ tidak terdeteksi adanya kadar. Kesimpulan : Ikan sidat (Anguilla marmorata (Q.) Gaimard) fase elver asal danau Poso dapat dijadikan sumber vitamin $\mathrm{B}_{2}, \mathrm{~B}_{3}$, dan $\mathrm{B}_{12}$.

Kata Kunci: Vitamin B, Anguilla marmorata, fase elver, KCKT

*Korespondensi: Telp: +62 81247563236 , Email : fenti.nasir@yahoo.com

\section{PENDAHULUAN}

Sidat (Anguilla sp.) merupakan ikan dari ordo $A n$ guilliformes yang tergolong dalam ikan katadromus.Ikan katadromus yaitu ikan yang bermigrasi diantara perairan tawar dan air laut (Hakim et al., 2015). Fase perkembangan sidat dimulai dari telur-telur yang telah dibuahi menetas menjadi fase proleptochephale, kemudian berkembang menjadi leptochephale selanjutnya leptochephale berkembang manjadi larva sidat yang disebut glass eel (Sasongko et at., 2007).

Fase glass eel dengan umur SF (short finned) 4,5-7 bulan dengan panjang 55-60 mm, LF (long finned)
5,5-6,5 bulan dengan panjang 50-55 $\mathrm{mm}$, fase elver umur $<1,5$ tahun dengan panjang $\leq 30 \mathrm{~cm}$, yellow eel umur $>5$ tahun dengan panjang $>30 \mathrm{~cm}$, dan silver eel umur 10-20 tahun lebih (McKinnon, 2006)

Daerah penyebaran sidat di Indonesia meliputi Sumatera, Jawa, Kalimantan, Bali, Nusa Tenggara, Maluku, Papua dan Sulawesi. Keberadaan ikan sidat di Sulawesi terdapat dibeberapa daerah yaitu, perairan Sulawesi Selatan, Sulawesi Utara, Gorontalo, Sulawesi Barat, dan Sulawesi Tengah (Fahmi, 2015). 
Sulawesi Tengah khususnya wilayah Poso memiliki potensi ikan sidat yang cukup tinggi karena didukung oleh Teluk Tomini yang cukup dalam serta keberadaan darat yang cukup luas (McKinnon, 2006)..Hasil tangkapan ikan didanau Poso didominasi oleh jenis ikan sidat yaitu sekitar $40 \%$ dari total tangkapan sebesar 75,54 ton/tahun (Putri et a., 2016) Anguilla marmorata merupakan jenis ikan sidat yang mendominasi hasil tangkapan ikan sidat yang berasal dari danau Poso (Triyanto et al., 2008). Sidat memiliki kandungan nutrisi yang tinggi seperti EPA (Eicosapentaeonic acid) yang lebih dikenal dengan omega-3, DHA (Docosahexaeonic acid), dan vitamin (Sudaryono et al., 2013).

Vitamin merupakan zat-zat organik kompleks yang diperlukan tubuh dalam jumlah yang kecil (Yuniastuti, 2008). Menurut Winarno (2004) vitamin dikelompokkan dalam 2 golongan besar yaitu vitamin larut lemak meliputi vitamin A, D, E, dan $\mathrm{K}$ dan vitamin larut air yang meliputi vitamin B dan Vitamin C. Vitamin larut lemak diangkut ke hati melalui sistem limfa sebagai bagian dari lipoprotein dan sebagian besar vitamin larut air merupakan komponen sistem enzim yang membantu metabolisme energi (Yuniastuti,2008). Vitamin tidak dapat disintetis oleh tubuh, maka dari itu untuk memenuhi kebutuhan vitamin dapat diperoleh dari makanan.Salah satu vitamin yang berperan penting dalam metabolisme adalah vitamin B (Mutschler, 1991).

Vitamin B merupakan vitamin larut air yang terdiri dari tiamin (vitamin B1), riboflavin (vitamin B2), niasin (vitamin B3), piridoksin (vitamin B6), asam folat/ folasin (vitamin B9), dan sianokobalamin (vitamin B12) (Winarno, 2004).Vitamin B1 (Tiamin Hidroklorida) berperan dalam metabolisme glukosa, lipid dan neurotransmitter (Cook et al., 1998). Kekurangan tiamin dapat menyebabkan polyneuritis. Dalam makanan tiamin dapat ditemukan dalam bentuk bebas atau bentuk kompleks dengan protein atau kompleks proteinfosfat (Winarno, 2004).

Vitamin B2 (riboflavin) merupakan bagian dari dua koenzim, yaitu riboflavin fosfat atau flavin mono nukleotida (FMN) dan flavin adenine dinukleotida (FAD) (Winarno, 2004). Riboflavin juga berperan sebagai unsur sistem enzim pernapasan jaringan dan beberapa enzim yang terlibat dalam metabolisme asam amino dan lipid (Yuniastuti, 2008).Vitamin B3 (niasin atau asam nikotinat) berperan dalam reaksi enzimatik dalam tubuh atau metabolisme karbohidrat, lemak dan protein.Koenzim tersebut adalah nicotinamide adenine dinucleotide (NAD) dan nicotinamide adenine dinucleotide phosphate (NADP). Kekurangan niasin yang parah selama beberapa bulan dapat mengakibatkan pellagra(Winarno, 2004). Vitamin B6 terdapat dalam sistem enzimatik yang berperan dalam proses metabolisme asam amino yang berarti diperlukan dalam proses metabolisme protein (Kartaspoetra et al., 2010). Vitamin B9 (Asam folat/ Folasin) diperlukan tubuh dalam proses metabolik dan pembentukan sel-sel darah merah sehingga asam folat baik digunakan dalam pengobatan anemia (Kartaspoetra et al., 2010).

Vitamin B12 (sianokobalamin) diperlukan dalam pembentukan sel darah, metabolisme, pertumbuhan jaringan dan pemeliharaan saraf. Vitamin B12 dapat diperoleh dari makanan seperti daging, ikan, telur dan produk susu (Kurnia Dewi et al., 2013).

Sumber vitamin B merupakan vitamin yang larut air banyak terdapat dalam daging ikan, minyak ikan, biji-bijian, kacang tanah, kacang kedelai dan sebagainya (Mutschler, 1991). Berdasarkan hasil penelitian pada beberapa ikan air tawar yang telah dilakukan oleh Taufiqurrahman (2008) pada ikan gurami (Osphronemus gouramy) didapatkan 0,033mg/100g vitamin $\mathrm{B}_{1}, \quad 0,0837 \mathrm{mg} / 100 \mathrm{~g}$ vitamin $\mathrm{B}_{2}$, dan $1,25 \mathrm{mg} / 100 \mathrm{~g}$ vitamin $\mathrm{B}_{3}$. Penelitian lain yang telah dilakukan oleh Hafiludin (2015) pada ikan bandeng (Chanos chanos) air tawar dan air payau didapatkan hasil pada bandeng air tawar $3,481 \mathrm{mg} / 100 \mathrm{~g}$ vitamin $\mathrm{B}_{12}$, dan $0,057 \mathrm{mg} / 100 \mathrm{~g}$ vitamin $\mathrm{B}_{1}$ sedangkan ikan bandeng air payau didapatkan hasil $3,965 \mathrm{mg} / 100 \mathrm{~g}$ vitamin $B_{12}$ dan $0,049 \mathrm{mg} / 100 \mathrm{~g}$ vitamin $\mathrm{B}_{1}$. Selain itu sidat juga merupakan salah satu ikan yang memiliki kandungan nutrisi yang tinggi salah satunya adalah vitamin seperti vitamin $\mathrm{A}, \mathrm{B}_{1}, \mathrm{~B}_{2}, \mathrm{~B}_{6} \mathrm{C}$, dan $\mathrm{D}$ (Sasongko, 2017).

Vitamin $\mathrm{B}$ terdiri dari vitamin $\mathrm{B}_{1}, \mathrm{~B}_{2}, \mathrm{~B}_{3}, \mathrm{~B}_{6}, \mathrm{~B}_{9}$ dan $B_{12}$.Kandungan kadar vitamin $B$ pada ikan sidat sendiri belum diketahui, makapada penelitian ini perlu dilakukan penelitian mengenai kadar vitamin $\mathrm{B}\left(\mathrm{B}_{1}, \mathrm{~B}_{2}\right.$, $\mathrm{B}_{3}, \mathrm{~B}_{6}, \mathrm{~B}_{9}, \mathrm{~B}_{12}$ ) pada ikan sidat asal danau Posojenis (Anguilla marmorata (Q.) Gaimard) fase elver.Pemilihan fase elver karena pada fase ini merupakan fase peralihan antara fase glass eel dan fase yellow eel, di mana pada fase ini merupakan fase pertumbuhan ikan sidat yang membutuhkan nutrisi tinggi termasuk vitamin untuk membantu proses metabolisme sehingga memungkinkan adanya vitamin yang terkandung pada fase ini

\section{BAHAN DAN METODE \\ 2.1 Bahan}

Pada penelitian ini bahan yang diperlukan antara lain: ikan sidat faseelver (sampel) Asal Danau Poso Sulawesi Tengah, Analisis vitamin menggunakan bahan-bahan, seperti asam formiat (p.a), metanol (p.a), aquabidest, amonium asetat (p.a), natrium hidrogen fosfat (p.a), asetonitril (p.a), asam fosfat (p.a), standart baku vitamin $\mathrm{B}\left(\mathrm{B}_{1}, \mathrm{~B}_{2}, \mathrm{~B}_{3}, \mathrm{~B}_{6}, \mathrm{~B}_{9}\right.$ dan $\left.\mathrm{B}_{12}\right)$

\subsection{Prosedur Pengambilan Sampel}

Teknik pengambilan sampel dilakukan dengan metode purposive sampling. Menurut Swarjana (2012), purposive sampling suatu teknik pengambilan sampelberdasarkan kebijakan peneliti berdasarkan kriteria yang telah ditentukan, yaitu berdasarkan jenis berat, ukuran dan lokasi pengambilan. Jenis sampel yang di ambil yaitu ikan sidat (Anguilla marmorata (Q.) Gaimard) dengan panjang 10 sampai $\leq 30 \mathrm{~cm}$ dangan umur 7 sampai $\leq 1,5$ tahun. Lokasi pengambilan sampel di danau Poso .

\subsection{Preparasi Sampel}

Ikan ditangkap menggunakan jaring di daerah danau Poso kemudian dimasukkan kedalam wadah polystryene dan diberi es. Selanjutnya dibersihkan kotorannya dan dicuci menggunakan air mengalir, kemudian dihaluskan dengan blender hingga homogen dan ditempatkan dalam wadah yang bersih dan tertutup, disimpan dalam freezer sampai saatnya dianalisis

\subsection{Prosedur Analisis}


a. Analisis vitamin $\mathbf{B}_{1}, \mathbf{B}_{2}, \mathbf{B}_{3}, \mathbf{B}_{6}, \mathbf{B}_{\mathbf{9}}$

Pembuatan larutan standar induk $B_{1}, B_{2}, \quad B_{3}$ (niacinamide), $\mathbf{B}_{6}, \mathbf{B}_{9}$

Di timbang standar baku $\mathrm{B}_{1}, \mathrm{~B}_{3}$ (niacinamide), $\mathrm{B}_{6}$, $\mathrm{B}_{9}$ masing-masing $25 \mathrm{mg}$, masukkan kedalam labu ukur $25 \mathrm{ml}$ kemudian larutkan dengan natrium hidrogen fosfat $0,05 \mathrm{M} \mathrm{pH}$ 6,30 sonifikasi selama 10-15 menit, kemudian tambahkan dengan natrium hidrogen fosfat $0,05 \mathrm{M} \mathrm{pH}$ 6,30hingga tanda tera dan homogenkan. Diperoleh standar baku dengan konsentrasi 1000 ppm. Encerkan hingga konsentrasi 100 ppm dan $10 \mathrm{ppm}$.

Di timbang standar baku $\mathrm{B}_{2} 10 \mathrm{mg}$ masukkan kedalam labu ukur $100 \mathrm{ml}$ larutkan dengan aquabidest, simpan dalam waterbath dengan suhu $100^{\circ} \mathrm{C} \pm 1$ menit dinginkan dengan suhu ruang kemudian tambahkan dengan aquabidest hingga tanda tera dan homogenkan. Diperoleh standar dengan konsentrasi 100 ppm. Encerkan hingga konsentrasi 10 ppm.

$\begin{array}{llllll}\text { Preparasi deret standar } & \mathbf{m i x} & \mathbf{B}_{1}, & \mathbf{B}_{2}, & \mathbf{B}_{\mathbf{3}}\end{array}$ (niacinamide), $\mathbf{B}_{6}, \mathbf{B}_{9}$

Dipipet larutan standar 10 ppm 0,$1 ; 0,25 ; 0,5 ; 0,75$ $\mathrm{ml}$ dan 100 ppm 0,$1 ; 0,25 ; 0,5 ; 0,75 ; 1 ; 1,5 \mathrm{ml}$ kedalam labu ukur $10 \mathrm{ml}$ larutkan dan himpitkan dengan natrium hidrogen fosfat $0,05 \mathrm{M} \mathrm{pH}$ 6,30 hingga tanda tera dan homogenkan. Diperoleh konsentrasi deret standar 0,$1 ; 0,25 ; 0,5 ; 0,75 ; 1 ; 2,5 ; 5 ; 7,5 ; 10$; dan 15 ppm.

\section{Pengujian sampel}

Di timbang sampel sebanyak 3 gram, larutkan dengan natrium hidrogen fosfat $0,05 \mathrm{M} \mathrm{pH} 6,30$ dalam labu takar $50 \mathrm{ml}$, sonikasi larutan selama 10-15 menit kemudian tambahkan natrium hidrogen fosfat $0,05 \mathrm{M}$ pH 6,30 hingga tanda tera lalu homogenkan. Masukan $2 \mathrm{ml}$ kedalam tabung kemudian sentrifugasi dengan $14000 \mathrm{rpm}$ selama 25 menit saring dengan minisart $\mathrm{RC} 0,20 \mu \mathrm{m}$. Larutan sampel siap untuk di injeksikan ke KCKT.
- Fase gerak :A-asam fosfat 0,1\% B -asetonitril pure

- Sistem : gradien

- Kecepatan alir:0,2ml/menit

- Kolom: acquityBEH C18 1,7 $\mu \mathrm{m}(2,1$ x $50 \mathrm{~mm})$

- Detektor : PDA

- Suhu : $40^{\circ} \mathrm{C}$

- Volume injeksi: $5 \mu 1$

b. Analisis Vitamin $B_{12}$

Preparasi Standar Vitamin $B_{12}$

Ditimbang $10 \quad \mathrm{mg}$ standar vitamin $\mathrm{B}_{12}$ (sianokobalamin) dimasukkan kedalam labu ukur 10 $\mathrm{ml}$ dilarutkan dengan metanol 10\% hingga tanda tera. Di buat deret standar dengan konsentrasi $1 ; 2,5 ; 5 ; 10$; 25; 50 dan $100 \mathrm{ppb}$ kemudian disaring dengan filter $0,2 \mu \mathrm{m}$.

\section{Pengujian Sampel}

Ditimbang sampel sebanyak 5 gram dimasukkan kedalam tabung sentrifugasi $50 \mathrm{ml}$ ditambahkan $25 \mathrm{ml}$ asam format $\mathrm{pH}$ 3,5 kocok selama 10 menit. Kemudian disentrifugasi pada kecepatan $4500 \mathrm{rpm}$ dengan suhu $4^{\circ} \mathrm{C}$. Di bilas catridge HLB dengan $3 \mathrm{ml}$ metanol dan 3 $\mathrm{ml}$ aquabidest. Di piat $3 \mathrm{ml}$ supernatan kedalam oasis HLB, dielusi dengan $3 \mathrm{ml}$ metanol. Filtrat kemudian dievaporasi dengan turbovap dan direkonstitusi dengan $1 \mathrm{ml}$ metanol 10\% disaring dengan filter $0,2 \mu \mathrm{m}$. Larutan sampel siap untuk di injeksikan ke alat LC MS

Kolom: YMC-Triart C18 1,9 $\mu \mathrm{m}, 2,1$ x50 mm

Fase gerak:A-10 mM ammonium asetat dan 0,1\% asam format dalam air B-10 mM ammonium asetat dan $0,1 \%$ asam format dalam metanol

Kecepatan alir:0,5ml/menit

Sistem pompa: Gradien

Volume injeksi : $2 \mu \mathrm{L}$

\section{HASIL}

Penentuan kadar vitamin $\mathrm{B}_{1}, \mathrm{~B}_{2}, \mathrm{~B}_{3}$, $\mathrm{B}_{6}$ dan $\mathrm{B}_{9}$ menggunakan metode kromatografi cair kinerja tinggi (KCKT) dan penetuan kadar vitamin $\mathrm{B}_{12}$ menggunakan metode kromatografi cair-spektroskopi massa (LC/MS). Data hasil pengujian kadar vitamin B

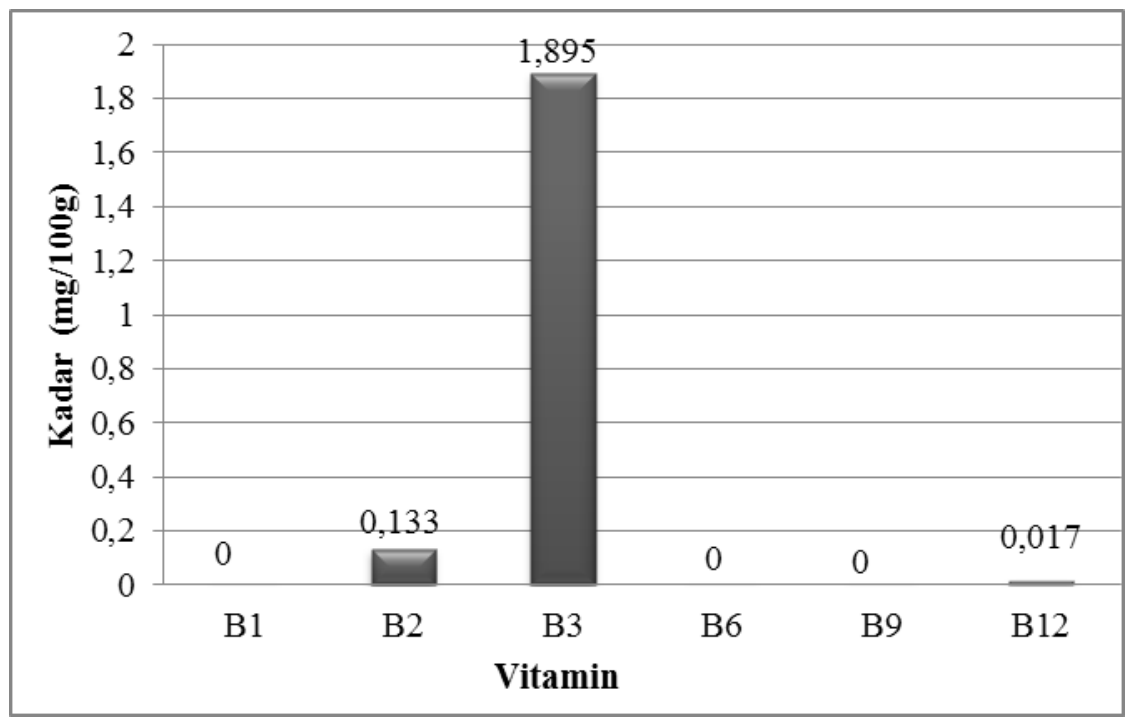

Gambar .1 Hasil analisis kadar vitamin $\mathrm{B}\left(\mathrm{B}_{1}, \mathbf{B}_{2}, \mathrm{~B}_{3}, \mathrm{~B}_{6}, \mathbf{B}_{9}, \mathbf{B}_{12}\right)$ ikan sidat (Anguilla marmorata(Q.) Gaimard) fase elver asal danau Poso 
$\left(\mathrm{B}_{1}, \mathrm{~B}_{2}, \mathrm{~B}_{3}, \mathrm{~B}_{6}, \mathrm{~B}_{9} \mathrm{~B}_{12}\right)$ yang telah dilakukan pada ikan sidat (Anguilla marmorata(Q.) Gaimard) fase elver asal Danau Poso dapat dilihat pada gambar 1

\section{PEMBAHASAN}

Sidat merupakan ikan konsumsi yang sangat digemari dibanyak negara khususnya Jepang, Cina, Jerman dan Prancis (Rovara, 2010).Hal tersebut karena sidat memiliki kandugan gizi yang lebih baik dibanding ikan lainnya (Shiraishi \& Crook, 2015).Selain itu sidat juga merupakan salah satu ikan yang memiliki kandungan nutrisi yang tinggisalah satunya adalah vitamin seperti vitamin $\mathrm{A}, \mathrm{B}_{1}, \mathrm{~B}_{2}, \mathrm{~B} 6, \mathrm{C}$, dan $\mathrm{D}$ (Sasongko, 2017).

Sulawesi Tengah khususnya wilayah Poso memiliki potensi ikan sidat yang cukup tinggi karena di dukung oleh Teluk Tomini yang cukup dalam serta keberadaan darat yang cukup luas (McKinnon, 2006). Hasil tangkapan ikan di Danau Poso didominasi oleh jenis ikan sidat yaitu sekitar $40 \%$ dari total tangkapan sebesar 75,54 ton/tahun (Putri et al, 2016) Anguilla marmorata merupakan jenis ikan sidat yang mendominasi hasil tangkapan ikan sidat yang berasal dari Danau Poso (Lukman dan Said, 2008). Pada penelitian ini Pemilihan fase elver karena pada fase ini merupakan fase peralihan antara fase glass eel dan fase yellow eel, di mana pada fase ini merupakan fase pertumbuhan ikan sidat yang membutuhkan nutrisi tinggi termasuk vitamin untuk membantu proses metabolisme sehingga memungkinkan adanya vitamin yang terkandung pada fase ini.

Teknik pengambilan sampel dilakukan dengan metode purposive sampling. purposive sampling adalah suatu teknik pengambilan sampelberdasarkan kebijakan peneliti berdasarkan kriteria yang telah ditentukan, yaitu berdasarkan jenis berat, ukuran dan lokasi pengambilan (Swarjana, 2012). Jenis sampel yang di ambil yaitu ikan sidat (Anguilla marmorata(Q.) Gaimard) dengan panjang 10 sampai $\leq 30 \mathrm{~cm}$ dangan umur 7 sampai $\leq 1,5$ tahun. Lokasi pengambilan sampel di danau Poso. Sampel dibersihkan terlebih dahulu, dicuci dengan air mengalir hingga bersih, selanjutnya sampel dipotong dan diblender hingga homogen, kemudian dimasukkan kedalam wadah bersih dan disimpan hingga akan dianalisis.

Analisis vitamin $\mathrm{B}_{1}, \mathrm{~B}_{2}, \mathrm{~B}_{3}, \mathrm{~B}_{6}, \quad$ dan $_{9}$ pada penelitian ini menggunakan metode HPLC.Komposisi vitamin dapat ditentukan menggunakan HPLC (Robinson et al., 2001).Sifat hidrofilik yang tidak mudah menguap dari vitamin larut air seperti vitamin B dapat dianalisis dengan HPLC.Keunggulan utama HPLC adalah kemampuannya untuk memisahkan vitamin dari matriks makanan yang kompleks (Nollet et al., 2013). Penggunaan HPLC dapat digunakan sebagai metode khusus dan sensitif yang dapat dikembangkan dalam penentuan beberapa vitamin dalam bahan makanan, di antara banyak metode yang dianjurkan. Vitamin yang paling sering diuji merupakan dalam bentuk bebas, meliputi hidrolisis dari bentuk fosforilase (Ndaw et a., 2000). Sedangkan pada analisis vitamin $\mathrm{B}_{12}$ menggunakan metode LC-MS, yaitu suatu teknik analisis kimia yang mempunyai kemampuan pemisahan yang sangat bagus, karena mempunyai sensitifitas dan spesifisitas yang sangat tinggi, karena teknik ini menggunakan kombinasi tandom kromatografi cair dan spektroskopi massa (Khairan et al., 2009). Pada KCKT kolom merupakan bagian yang sangat penting, karena pemisahan komponenkomponen sampel terjadi di dalam kolom (Susanti dan Dachrriyanus, 2017).Kolom yang digunakan adalah Acquity BEH C18. Menurut Nollet (2013) kolom C 18 dapat digunakan pada penetuan vitamin larut air seperti dan B. Kolom ini mampu memisahkan senyawa dengan kepolaran yang rendah, sedang maupun tinggi (Gandjar dan Rohman, 2008).

Detektor yang digunakan adalah PDA (photodiodearray) dapat menampilkan kromatogram pada panjang gelombang yang di inginkan (biasanya antara 190-400 $\mathrm{nm}$ ) detector ini mampu memberikan kumpulan kromatogram secara simultan pada panjang gelombang yang berbeda dalam sekali proses, selektif terhadap gugus dan struktur yang tidak jenuh (Gandjar dan Rohman, 2008). Detector PDA memungkinkan untuk penetuan senyawa secara simultan dengan teliti pada panjang gelombang yang berbeda dengan demekian deteksi pada PDA dapat member daya serap tinggi dari setiap vitamin sehingga dapat digunakan untuk pada penetuan kadar vitamin larut air (vitamin $\mathrm{C}$ dan B) pada panjang gelombang tertentu (Antakli, Sarkees, \& Sarraf, 2015).

Hasil analisis kadar vitamin $\mathrm{B}\left(\mathrm{B}_{1}, \mathrm{~B}_{2}, \mathrm{~B}_{3}, \mathrm{~B}_{6}, \mathrm{~B}_{9}\right.$, danB $\mathrm{B}_{12}$ ) pada ikan sidat (Anguilla marmorata $(\mathrm{Q}$.) Gaimard) fase elver asal danau Poso (Grafik 4.1) menunjukkan bahwa kadar tertinggi yaitu pada vitamin $\mathrm{B}_{3}$ dengan kadar $1,895 \mathrm{mg} / 100 \mathrm{~g}$, vitamin $\mathrm{B}_{2}$ dengan kadar $0,133 \mathrm{mg} / 100 \mathrm{~g}$, dan vitamin $\mathrm{B}_{12}$ dengan kadar 0,017 $\mathrm{mg} / 100 \mathrm{~g}$ sedangkan pada vitamin $\mathrm{B}_{1}, \mathrm{~B}_{6}$, dan $\mathrm{B}_{9}$ hasil tidak terdeteksi. Vitamin pada ikan hanya dapat di peroleh dari sumber makanannya, ikan tidak dapat mensintesis vitamin dalam tubuhnya sendiri untuk membantu proses metabolisme. Besar kecilnya vitamin dalam tubuh ikan di tentukan dari sumber makanan yang diperoleh (Jusadi et al, 2006).

Vitamin B1 (Tiamin Hidroklorida) adalah salah satu contoh vitamin B yang larut air yang terlibat dalam metabolisme glukosa dan lipid serta produksi neurotransmitter (Cook et al., 1998). Pada prinsipnya tiamin berperan sebagai koenzim dalam berbagai reaksi yang terlibat untuk menghasilkan energi dari karbohidrat dan memindahkan energi yang membentuk senyawa kaya energi yang disebut ATP (adenine trifosfat). Kekurangan tiamin dapat menyebabkan polyneuritis, yang dikarenakan terganggunya transmisi saraf, atau jaringan saraf yang menderita kekurangan energi.Dari analisis vitamin $\mathrm{B}_{1}$ pada ikan sidat (Anguilla marmorata(Q.) Gaimard) fase elver asal danau Poso tidak dapat memenuhi vitamin $\mathrm{B}_{1}$ yang dibutuhkan tubuh karena hasil yang diperoleh tidak terdeteksi sehingga ikan sidat (Anguilla marmorata(Q.) Gaimard) fase elver asal danau Poso tidak dapat dijadikan sumber vitamin $\mathrm{B}_{1}$.

Vitamin B2 (Riboflavin) merupakan komponen suatu sistem enzim yang dikenal sebagai flavoprotein dan terlibat dalam reaksi-reaksi metabolisme intermediet.Riboflavin merupakan bagian dari dua koenzim, yaitu riboflavin fosfat atau flavin mono nukleotida (FMN) dan flavin adenine dinukleotida (FAD) (Winarno, 2004).Riboflavin juga berperan sebagai unsur sistem enzim pernapasan jaringan dan beberapa enzim yang terlibat dalam metabolisme asam amino dan lipid (Yuniastuti, 2008). Dari hasil analisis vitamin $\mathrm{B}_{2} \mathrm{di}-$ peroleh $0,13 \mathrm{mg} / 100 \mathrm{~g}$ pada ikan sidat (Anguilla marmorata(Q.) Gaimard) fase elver asal danau Poso, sehingga dengan mengonsumsi sebanyak 100 gram ikan sidat (Anguilla marmorata(Q.) Gaimard) fase elver asal danau Poso dapat menyumbang vitamin $\mathrm{B}_{2}$ sebesar 0,13 
mg (bb) atau sekitar 8,67\% dari angka kecukupan gizi dengan asumsi daya serap vitamin B2 adalah $100 \%$.

Vitamin $\mathrm{B}_{3}$ (niasin) sangat mudah diserap diusus kecil, dan beberapa cadangannya dapat disimpan dalam tubuh.Niasin berperan dalam reaksi enzimatik dalam tubuh atau metabolisme karbohidrat, lemak dan protein.Koenzim tersebut adalah nicotinamide adenine dinucleotide (NAD) dan nicotinamide adenine dinucleotide phosphate (NADP).Keduanya bertindak sebagai penerima hidrogen.Kekurangan niasin yang parah selama beberapa bulan dapat mengakibatkan pellagra dengan gejala spesifik yaitu sakit tenggorokan, lidah dan mulut, serta dermatitis yang khas (Winarno, 2004). Dari hasil analisis vitamin $B_{3}$ diperoleh 1,91 $\mathrm{mg} / 100 \mathrm{~g}$ pada ikan sidat (Anguilla marmorata(Q.) Gaimard) fase elver asal danau Poso, sehingga dengan mengonsumsi sebanyak 100 gram ikan sidat (Anguilla marmorata(Q.) Gaimard) fase elver asal danau Poso dapat menyumbang vitamin $B_{3} 1,91 \mathrm{mg} / 100 \mathrm{~g} \mathrm{(bb)} \mathrm{atau}$ sekitar $16 \%$ dari angka kecukupan gizi dengan asumsi daya serap $100 \%$.

Vitamin B6 terdapat dalam sistem enzimatik yang berperan dalam proses metabolism asam amino (Kartaspoetra et al., 2010). Piridoksal fosfat adalah gugus prostetik enzim yang melakukan dekarboksilasi tirosin, asam glutamate dan asam amino tertentu lainnya. Berperan penting dalam proses transulfurasi dan dalam perubahan triptofan menjadi niasin, juga sebagai koenzim dalam transminasi. Berperan dalam metabolism asam lemak esensial, penting dalam sintetis porfirin (missal hem untuk hemoglobin dan sitokrom) (Yuniastuti, 2008). Dari analisis vitamin $\mathrm{B}_{6}$ pada ikan sidat (Anguilla marmorata(Q.) Gaimard) fase elver asal danau Poso tidak dapat memenuhi vitamin $\mathrm{B}_{6}$ yang dibutuhkan tubuh karena hasil yang diperoleh tidak terdeteksi sehingga ikan sidat (Anguilla marmorata(Q.) Gaimard) fase elver asal danau Poso tidak dapat dijadikan sumber vitamin $\mathrm{B}_{6}$.

Vitamin $\mathrm{B}_{9}$ (asam folat) sebagian besar disimpan dalam hati.Perubahan asam folat menjadi folasin (asam folinat) terjadi dalam hati.Asam folinat merupakan bentuk aktif dari asam folat.Asam folinat merupakan koenzim untuk beberapa sistem enzim. Salah satu peranan utamanya adalah biosintetis dan pemindahan satu satuan karbon seperti gugus metil yang berarti memungkinkan terjadiya sintetis metionin, kolina, dan penambahan gugus metil pada pirimidina sehingga terbentuk tiamina. Asam folinat juga berperan penting dalam dalam proses sintetis nukleo protein yang berperan penting dalam pembentukan dan produksi butirbutir darah merah normal dalam susunan tulang. Asam folat juga terlibat dalam proses oksidasi fenilalanin menjadi tirosin (Winarno, 2004). Dari analisis vitamin B9 pada ikan sidat (Anguilla marmorata(Q.) Gaimard) fase elver asal danau Poso tidak dapat memenuhi vitamin $\mathrm{B}_{9}$ yang dibutuhkan tubuh karena hasil yang diperoleh tidak terdeteksi sehingga ikan sidat (Anguilla marmorata(Q.) Gaimard) fase elver asal danau Poso tidak dapat dijadikan sumber vitamin $\mathrm{B}_{9}$.

Vitamin B12 (sianokobalamin) berperan dalam menjaga agar sel-sel berfungsi normal terutama sel-sel pencernaan, sistem urat saraf, dan sum-sum tulang. Dalam sum-sum tulang koenzim vitamin B12 sangat diperlukan untuk sintetis DNA. Vitamin B12 juga diperlukan oleh enzim yang berfungsi dalam sintetis dan pemindahan satu unit karbon seperti gugus metil, dan dalm sintetis metionin dan kolin yang dibantu oleh faktor lain yang disebut faktor lipotropik (Winarno, 2004). Dari hasil analisis vitamin $B_{12}$ diperoleh $0,017 \mathrm{mg} / 100 \mathrm{~g}$ pada ikan sidat (Anguilla marmorata (Q.) Gaimard) fase elver asal danau Poso, sehingga dengan mengonsumsi sebanyak 100 gram ikan sidat (Anguilla marmorata(Q.) Gaimard) fase elver asal danau Poso dapat menyumbang vitamin $\mathrm{B}_{12} 0,017 \mathrm{mg}$ (bb) atau sekitar $21,68 \%$ dari angka kecukupan gizi dengan asumsi daya serap $30 \%$.

Pada beberapa penelitian mengenai vitamin B pada ikan yang telah dilakukan oleh Taufiqurrahman (2008) pada ikan gurami (Osphronemus gouramy) didapatkan $0,033 \mathrm{mg} / 100 \mathrm{~g}$ vitamin $\mathrm{B}_{1} 0,0837 \mathrm{mg} / 100 \mathrm{~g}$ vitamin $\mathrm{B}_{2}$, dan $1,25 \mathrm{mg} / 100 \mathrm{~g}$ vitamin $B_{3}$. Penelitian lain yang telah dilakukan oleh Hafiludin (2015) pada ikan bandeng(Chanos chanos) air tawar dan air payau didapatkan hasil pada bandeng air tawar $3,481 \mathrm{mg} / 100 \mathrm{~g}$ vitamin $\mathrm{B}_{12}$ dan $0,057 \mathrm{mg} / 100 \mathrm{~g}$ vitamin $\mathrm{B}_{1}$ sedangkan ikan bandeng air payau didapatkan hasil $3,965 \mathrm{mg} / 100 \mathrm{~g}$ vitamin $\mathrm{B}_{12}$ dan $0,049 \mathrm{mg} / 100 \mathrm{~g}$ vitamin $\mathrm{B}_{1}$, ini menunjukkan bahwa ikan dapat menjadi salah satu sumber vitamin B untuk memenuhi kebutuhan vitamin tubuh untuk membantu proses metabolism.

\section{KESIMPULAN}

Kadar vitaminB $B_{2}, B_{3}$, dan $B_{12}$ pada ikan sidat (Anguilla marmorata(Q.) Gaimard) fase elver asal danau Poso secara berturut-turut adalah $0,133 \mathrm{mg} / 100 \mathrm{~g}$, $1,895 \mathrm{mg} / 100 \mathrm{~g}$, dan $0,017 \mathrm{mg} / 100 \mathrm{~g}$. Sedangkan pada vitamin $\mathrm{B}_{1}, \mathrm{~B}_{6}$, dan $\mathrm{B}_{9}$ tidak terdeteksi

\section{DAFTAR PUSTAKA}

Antakli, S., Sarkees, N., \& Sarraf, T. (2015). Determination of water-soluble vitamins $\mathrm{B}_{1}, \mathrm{~B}_{2}, \mathrm{~B}_{3}, \mathrm{~B}_{6}$, $\mathrm{B}_{9}, \mathrm{~B}_{12}$, and $\mathrm{C}$ on $\mathrm{C} 18$ with particle size $3 \mu \mathrm{M} \mathrm{I}$ some manufactured food products by HPLC with UV-DAD/FLD detection. International Journal of Pharmacy and Pharmaceutical Sciences, 7(6), 219-224.

Cook, C. C. H., Hallwood, P.M., \& Thomson, A.D. (1998). B vitamin deficiency and neuropsychiatric syndromes in alcohol and alcoholism. 33. 317-336.

Gandjar, I. G., \& Rohman, A. (2008).Kimia farmasi analisis. Yogyakarta: Pustaka pelajar.

Fahmi, M.R. (2015). Short communication conservation genetic of tropical eel in Indonesian waters based on populationgenetic study. Pros Sem Nas Masy Biodiv Indon, 1(1), 38-43. DOI:10.13057/psnnbi/m010106

Hafiludin. (2015). Analisis kandungan gizi pada ikan bandeng yang berasal dari habitat yang berbeda. Jurnal Kelautan, 8(1), 37-43.

Hakim, A. A., Kamal, M. M., Butet, N. A., Affandi, R. (2015). Komposis spesies ikan sidat (Anguilla Sp.) didelapan sungai yang bermuara ke pelabuhan Ratu, Sukabumi, Indonesia. Jurnal Ilmu dan Teknologi Kelautan Tropis,--7 (2), 573-585

Jusadi, D., Dewantara, B. A., dan Mokoginta, I. (2006). Pengaruh kadar L-Ascorbyl-2Phosphate magnesium yang berbeda sebagai sumber vitamin $\mathrm{C}$ dalam pakan terhadap pertumbuhan ikan patin Pangasius Hypophtalamus 
ukuran sejari. Jurnal Aquakultur Indonesian, 5 (1), 21-29.

Kartaspoetra, G., Marsetyo., dan Med. (2010). Ilmu gizi (korelasi gizi dan produktivitas kerja). Jakarta: Rineka Cipta.

Khairan., Jenie, U. A., Sudibyo, R. S. (2009). Fragmentation studies of $\Delta^{6-7}$-anhidroeritromisin-A by liquid chromatography-mas spectroscopy (LC-MS). Indo. J. Chem, 9(3), 491-499.

McKinnon, L.J. (2006), A review of eel biology:Knowledge and Gaps, EPA Victoria and Audentes Investments Pty, Ltd.

Mutschler, E.(1991). Dinamika obat. (edisi kelima). Penerjemah: Widianto M.B dan RiantiA.S. Bandung: Penerbit ITB.

Ndaw, S., Bergaentzé, M., Auodé-Werner, D., Hasselmann, C. (2000) Extraction procedures for the liquid chromatographic determination of thiamin, riboflavin and vitamin $\mathrm{B}$ in foodstuffs. Food Chemistry, 71, 128-138.

Nollet, L. M. (2000). Quantitative determination of water-soluble vitamins In Russel, L. F (ed.) Food analysisby HPLC.(PP 403-476). New York: Marcel dekker.

Putri, A. A. B., Yuliet., Jamaluddin. (2016). Analisis kadar albumin ikan sidat (Anguilla marmorata dan Anguilla bicolor) dan uji aktivitas penyembuhan luka terbukan pada keinci (Oryctolagus cuniculus). Galenika Journal of Pharmacy, 2(2), 90-95.

Robinson, E. H., Li, M.H., Oberle, D. F. (2001).Nutrients characteristic of pond-raised channel catfish.J Mississipi Agricultural and Forestry Experiment Station, 22, 12-76.

Rovara, O. (2010). Laporan akhir alih teknologi pemeliharaan benih ikan sidat teradaptasi di kawasan Segara Anakan, Badan pengkajian dan penerapan teknologi. Jakarta.

Sasongko, Aet al. (2007). Sidat; panduan agribisnis penangkapan, pendederan dan pembesaran. Jakarta: Penebar Swadaya.

Sasongko, H., Efendi, N. R., Budihardjo, A., Farida, Y., Amartiwi, T., Rahmawati, A. A., Wicaksono, A., Sugiyanto. (2017). Solvent and extraction methos effects on the quality of eel (Anguilla bicolor) oil. Journal of Physics. Conferensi Series, $795 \quad$ (2017) 012021. DOI:10.1088/1742-6596/795/1/012021.

Sudaryono, A., Putro, S. P., dan Susmito. (2013). Tinjauan potensi pengembangan dan aplikasi teknologi budidaya sidat. Konferensi Aquakultur Indonesia (hal. 383-388).

Susanti, M., Lena, D. I., Dachriyanus. (2014). Deve lopment and validation of a HPLC method for determination and quantification of rubraxanthone in stem bark extract of mangosteen. Indonesian Journal Pharmacy, 25(4), 237-244. DOI:10.14499/Indonesianjpharm25iss4pp237.

Swarjana, I. K. (2012). Metodologi penelitian kesehatan. Yogyakarta: Penerbit ANDI.

Taufiqurrahman. (2008). Komposisi kimia vitamin A, B1, B2, B3 daging ikan gurami (Osphronemus gouramy) pada berbagai ukuran.Skripsi.Fakultas perikanan dan ilmu kelautan. Institute Pertaian Bogor, Bogor.

Triyanto., Lukman., dan Said, D. S. (2008). Keragaman genetik ikan sidat (Anguilla marmorata) dari perairan Poso berdasarkan polimorfisme mitokondria DNAA D-Loop. Jurnal Iktilogi IndonesiaI, 8(2), 51-58.

Winarno, F. G. (2004). Kimia pangan dan gizi. Jakarta: PT gramedia

Yuniastuti, A. (2008). Gizi dan kesehatan. Yogyakarta: Graha ilmu. 